\title{
Globalization and Insecurity: Reviewing Some Basic Issues $^{\dagger}$
}

\author{
Michelle R. Garfinkel \\ University of California, Irvine \\ Stergios Skaperdas \\ University of California, Irvine \\ Constantinos Syropoulos \\ Drexel University
}

First version: November 2005

This version: July 2008

\begin{abstract}
We argue that the costs of domestic and transnational insecurity are large and economically significant and that they may vary with the trade regime of a country. Then, in evaluating trade regimes, the gains from trade need to be weighed against the change in the security costs they induce. Within a simple model of trade, small countries that import a contested resource unambiguously gain from free trade. However, exporters of a contested resource incur additional security costs that are higher than the gains from trade compared to autarky, as long as the international price of the contested resource is not too high. We conclude with a discussion of how domestic and transnational governance could reduce insecurity.
\end{abstract}

JEL Classification: D30, D70, D72, D74, F2, F10.

Keywords: globalization, trade openness, property rights, enforcement, insecurity.

\footnotetext{
${ }^{\dagger}$ This paper was written for presentation at the CESifo Conference on "Guns and Butter: The Economic Causes and Consequences of Conflict" December 9-10, 2005 in Munich. We thank Peter Rosendorff and other participants from the conference, as well as two anonymous referees, for helpful comments. We also thank the Center for Global Peace and Conflict Studies and the Center for the Study of Democracy, both at UC Irvine, for financial support.
} 
The hidden hand of the global market would never work without the hidden fist. And the hidden fist that keeps the world safe for Silicon Valley's technologies to flourish is called the United States Army, Air Force, Navy and Marine Corps (with the help, incidentally, of global institutions like the U.N. and the International Monetary Fund). And those fighting forces and institutions are paid for by all the tax dollars that Washington is "wasting" every year. [Thomas Friedman, "Techno-Nothings," New York Times, April 18, 1998).]

If we ask ... what would be the most powerful mechanism for ensuring that the forces of economic convergence overwhelm those of divergence, the answer has to be jurisdictional integration. [Martin Wolf (2004, p. 315).]

\section{Introduction}

Concepts like Thomas Friedman's "hidden fist" and Martin Wolf's "jurisdictional integration" are rarely, if ever, invoked in economic analyses of trade and globalization. That is not surprising given that such analyses are based on - or, at least, are intellectually inspired by-models of trade in which concerns about security and governance are completely absent. However, while abstracting from security concerns might be analytically convenient, in practice many goods that are traded internationally or are important inputs in the production of tradeable goods - oil, diamonds, land, water resources - are subject to contestation, either domestically by rival groups or internationally by different countries.

We shall first argue that insecurity has costs that are economically important. These costs include direct costs such as those of arming and destruction as well as more indirect ones due to distortions in production, consumption, and investment that are brought about by insecurity and conflict. In section 2 we discuss the various costs of domestic insecurity and their economic importance whereas in section 3 we examine the potential costs of transnational insecurity. 
Different trading regimes can be expected to induce different costs of insecurity, but how these costs vary with trading regimes has barely been investigated within economics. The "classical liberal" viewpoint-which, by default, appears to be the position shared by many economists - is that more liberal trading regimes tend to reduce conflict because the carrot of the gains from trade brings potential adversaries closer to one another. ${ }^{3}$ To our knowledge, there is no precise mechanism to which classical liberalism appeals, but the positive effects of trade on security can work through a variety of channels. For example, business contacts become personal contacts, increased trade strengthens diplomatic ties, and increased human contacts improve inter-cultural understanding. According to the liberal view, breaking down barriers to trade brings not only the familiar gains from trade, but also reduces costs of insecurity.

A sharply different perspective comes from the "realist" school of international relations. In particular, when one party trades with an adversary (either an actual or potential opponent), that party provides its opponent fuel for growth and enhanced military strength. ${ }^{4}$ That increase in the adversary's military strength, in turn, induces the party to expend more resources on security itself, thereby detracting from the gains that had been realized from trade. Indeed, according to the realist perspective, the increased security costs could very well offset the gains realized.

Are the liberals or are the realists right? Attempting to answer such a question requires a formal framework that can admit both trade and the costs of insecurity. In section 4, we examine such a framework that borrows from our previous work in Skaperdas and Syropoulos (2001) and Garfinkel, Skaperdas, and Syropoulos (forthcoming). Two "small" adversaries compete for a contested resource that can be used in the production of tradeable goods. ${ }^{5}$ The model we examine is simple enough in its symmetry such that

\footnotetext{
${ }^{3}$ Polachek (1980) is a rare articulation by an economist of the classical liberal perspective of the effect of trade on conflict.

${ }^{4}$ Waltz (1979) and Gowa (1995) are two prima elaborations of the realist perspective. Barbieri and Schneider (1999) report on the results of different recent political science studies from both schools.

${ }^{5}$ The parties are "small" in the sense that they have no effect on international prices.
} 
it allows for the two adversaries to be interpreted as either small countries or groups within a single country. The costs of insecurity, measured by the value of resources diverted from productive uses, vary with the degree to which the countries in which the parties operate are open to trade. We study, in particular, the two polar opposite regimes of autarky and free trade. In determining welfare in such a setting, the gains from free trade need to be weighed against the possibly higher costs of conflict that emerge in the autarkic outcome. The findings that we report include: (i) importers of the contested resource gain unambiguously under free trade; (ii) exporters of the contested resource lose under free trade when the international price of the resource is close enough to its autarkic price. Thus, even this simple framework indicates that the question of whether the liberals or the realists are correct in their views about trade cannot be answered unconditionally. And, yet this framework identifies specific and different conditions under which the liberal and realist views hold. Moving beyond the liberal-realist debate, our framework also provides new insights into the "natural resource curse" and a distortion in trade patterns that is brought about by insecurity.

Ultimately, the costs of insecurity and, as our analysis indicates, the effects of globalization depend on how effectively individual countries and the relationships between countries are governed. In section 5 we stress how economic globalization must be considered jointly with problems of governance and discuss dilemmas that are within today's time horizon and beyond.

\section{The Economic Relevance of Domestic Insecurity}

Since World War II civil wars have broken out in 73 countries, in many of them more than once, and the estimated death toll resulting directly from these conflicts is over 16 million [see Fearon and Laitin $\left(2003\right.$, p.75)]. ${ }^{6}$ The costs of arming and hiring combatants, the destruction of crops, structures, capital infrastructure, and many other collateral costs have been surveyed by researchers at the World Bank [see Collier et. al. (2003)].

\footnotetext{
${ }^{6}$ Fearon and Laitin (2003) base their findings on the Correlates of War project, among other sources. The definition of civil war uses the 1,000 deaths per year threshold.
} 
In addition, there are the usual - for economists - indirect costs of war that come from the static and dynamic misallocation of resources. Using the methodology developed by Lucas (1987) to estimate the welfare costs of the business cycle, Hess (2003) estimates the welfare costs of conflict coming from its effects on consumption alone for 147 countries spanning the period 1960-1992 to be on average 8 percent of steady-state consumption. The individual estimates for some countries are, not surprisingly, a bit smaller. For the United States, for example, the estimated cost is 3.2 percent. However, even this estimate is far greater than the Lucas-type estimate of the welfare cost of the business cycle in the United States [Hess (2003), p. 17]. Moreover, the estimates for some lower-income countries are dramatically higher - e.g., the cost is 65 percent in Iraq and 40.5 percent in Angola.

Civil wars are not the sole source of conflict and security costs. Rodrik (1998, 1999), for example, has drawn attention to distributional and social conflict, and the costs associated with them: strikes and lockouts, protests that sometimes become violent, military coups, ethnic, religious, or class rivalries, as well as common crime. The costs of such conflicts would perhaps be more difficult to estimate, but surely they are not negligible.

Another set of costs is associated with the public and private enforcement of property rights. Take as an example property rights in land, a key factor of production for which we would expect the property rights issue to be settled by the 21st century. However, for many middle and low-income countries property rights in land are publicly unenforceable, if they exist at all. The Russian Parliament voted a land law for urban areas a few years ago, but no such law exists for land in rural areas yet. In India, the problem is not the absence of law in land but the hopeless conflict of too many contradictory laws, based on different legal traditions that have not been resolved by the Indian state. Not surprisingly, then, as Lewis (2004, p.199) states: "It is not clear who owns land in India. Over 90 percent of land titles are unclear." In China, there are numerous land disputes between local municipal enterprizes and peasant farmers with traditional rights that have been reported and which threaten the country's social stability and 
economic growth in the future [see, e.g., Jacques, (2005)]. In the absence of effective public enforcement of law in land - which in itself is expensive but predictable - costly contests often take place for its private capture. However, even those who are able to privately appropriate land are unlikely to take the more efficient long-term actions that someone with clear title would.

Thus, from civil wars, to distributional conflict, to the private appropriation of land, insecurity and conflict are associated with large costs. It would be fair to say that these costs dwarf the (sometimes elusive) deadweight losses from Harberger triangles that dominate much of the study of inefficiency. Given the apparent economic significance of conflict costs, especially for low-income countries, it is surprising how little attention they have received among economists.

For our purposes here, it is important to note that many civil wars and lower-level conflicts have taken place in countries with natural resources like oil, diamonds, copper and other minerals, as well as those over the distribution of land. Many of these same countries also suffer from the "naturalresource curse," the tendency to have low or negative income growth correlated with higher exports of natural resources. We have a possible explanation for this puzzle, presented below in section 4, that is based on the costs of insecurity.

\section{Insecurity in Interstate Relations}

Trade and financial transactions between parties located in different nationstates naturally take place within an anarchic setting. That is, there is no interstate authority that can serve as arbiter of disputes between those parties. Not surprisingly, then, wars between states have been continually taking place throughout recorded human history.

Since World War II, though, there have been fewer interstate wars than in the previous half century with the number of fatalities considerably less than those of the civil wars that have taken place over the same period. This relative calm, however, has not translated into lower levels of security 
costs. The superpower rivalry that existed between the United States and the Soviet Union throughout much of the latter half of the twentieth century left insecurity levels high. Thus, whereas the economic costs of destructive warfare were relatively low, nations continued to pour resources into their respective militaries, and the costs of insecurity were far from negligible.

The Cold War, while not a destructive war, was still a war of sorts. The coldness of the Cold War was partly due to the threat of nuclear annihilation, but it was also probably aided by the United Nations and other international institutions that, though highly imperfect and weak, were providing some semblance of predictability in international relations. For example, the concept of "collective security" and the reluctance of the two superpowers and their respective blocks to sanction changes in international borders provided a measure of cross-border stability that made states reluctant to engage in warfare against other states. ${ }^{7}$

The end of the Cold brought about the breakup of the Soviet Union, Yugoslavia, and Czechoslovakia, a uni-polar world, and, arguably, a weakening of the United Nations. Whether the relative interstate peace of the postWorld War II period can continue into the future remains unclear. There are two related though distinct problems that are likely to or have the potential to jeopardize that peace, and in doing so would severely threaten economic globalization. As we shall argue below, economic globalization itself without appropriate governance could actually hasten the onset of more conflictual relations between states.

The first threat comes from regional wars with resource contestation as its primary, but by no means sole, source. According to Klare (2001), conflict over resources between states has become more serious lately. Oil is, of course, the most important resource, but other minerals and also fresh water resources are gaining importance as well. Here we provide only a few

\footnotetext{
${ }^{7}$ That practice along with the principle of non-interference in the internal affairs of other states meant whoever controlled the capital of a country had international recognition as the legitimate government. That recognition and the high economic value it conferred to its holder might have made internal instability and civil warfare more likely than otherwise. Herbst (2000) has argued with reference to sub-Saharan Africa partly on those grounds against the recognition of international borders.
} 
examples of such potential sources and areas of conflict. The discovered and yet-to-be-discovered oil wealth of Central Asia is fuelling disputes and arming in the area and beyond that could approach a new "Great Game." The states surrounding the Caspian Sea-Russia, Kazakhstan, Turkmenistan, Iran, and Azerbaijan - have still not settled on a formula for dividing the rights of exploration and exploitation for oil. Where claims are settled, oil companies and their governments vie for contracts, rival pipeline routes, bids to buy local rights as well as local firms, and the whole endeavor is tinged with subterranean geopolitical calculations that involve the United States as well as all the lesser powers of Russia, China, and Europe. Further South, with the Iraq war, the Middle East has already become a new battleground with much uncertainty about where it will all lead. And, areas with suspected oil reserves like the South China Sea (around the Spratly and Paracel islands) have been already contested in minor hot incidents as well as diplomatically by seven countries (China, Taiwan, Vietnam, the Philippines, Indonesia, Malaysia, and Brunei).

Beyond oil, fresh water has perhaps been underrated for its potential to create havoc in many areas with rapidly increasing populations, economic growth, and economic globalization. It is not well-known, for instance, that Egypt has threatened its upstream neighbors, especially Ethiopia, with bombing water facilities if they were to go ahead with irrigations projects on the Nile [Klare (2001, p.153)]. In the coming years, the countries of the Upper Nile and the tributaries that drain into Lake Victoria (Sudan, Ethiopia, Kenya, Uganda, Tanzania, Rwanda, Burundi, Congo) will need to draw more water from the river, but any significant reductions in the downstream flow to Egypt could have catastrophic effects to the economy of that country. ${ }^{8}$ We cannot predict how, or whether, such disputes will be resolved peacefully. In the meantime, it should surprise no one if impoverished Ethiopia buys state-of-the-art anti-aircraft batteries. Some other examples of rivers that have induced or are likely to induce contention include the Jordan river (involving Israel, Jordan, Syrian, and the Palestinians), the Tigris

\footnotetext{
${ }^{8}$ Economic globalization intensifies demand for water resources primarily through the demand for water-intensive agricultural products, as is the case for Egyptian cotton.
} 
and Euphrates (involving Turkey, Syria, and Iraq), the Indus (Afghanistan, Pakistan, India), the Brahmaputra (China, India, and Bangladesh), and the Mekong (China, Thailand, Laos, Cambodia, and Vietnam).

The second type of insecurity that is looming on the horizon is the real or imagined rise of a peer competitor to the military and economic preeminence of the United States. The most widely mentioned and discussed candidate is China. Before September 2001 the role of China had been widely debated especially in connection with its WTO accession. The proponents of China's admission to the WTO were offering the liberal gains-from-trade and peace-through-trade arguments, whereas its opponents were offering the realist it-will-come-back-to-bite-you argument as well as more ideological arguments regarding the nature of China's polity and its relation to Taiwan. Although it would take China decades to become a genuine peer competitor to the US, in the absence of significant or prolonged measures not only to improve relations, but also to eliminate all suggestions of hostile intent on either side, the present calm could well turn out to be the calm before the storm. ${ }^{9}$ For the experience of the first instance of modern globalization is not encouraging.

Before 1914, burgeoning trade flows and German bankers living in London made war unthinkable for many commentators as it was reasonably expected that war would destroy economically winners and losers alike. As Norman Angell wrote in the best-selling The Great Illusion, published in 1909, "the capitalist has no country, and he knows, if he be of the modern type, that arms and conquests and jugglery with frontiers serve no ends of his, and may very well defeat them [quoted in Joll (1993, p. 161)]." But the rivalries between the European Great powers proved too great to overcome.

\footnotetext{
${ }^{9}$ Of course there is the possibility of other states becoming peer competitors to the United States, even some seemingly unexpected ones at the moment. For example, Japan possesses the nuclear and missile technologies to become a major nuclear power within a short period of time. While now Japan might not aspire to become a nuclear power, a confirmation of North Korea's nuclear status or higher perceived threats from China could well make Japan a nuclear power, after sufficient preparation of its domestic opinion. A nuclear Japan would radically change the world balance of power, even if it does not evolve to a US peer competitor.
} 
The initial trade openness gave in gradually to tariffs, other protective measures and eventually to the Great War.

Whether security costs are generated by neighboring states with resource disputes or by a potential geopolitical rivalry, the extent of trade openness can be expected to affect these costs. We turn next to an analysis of a setting with small countries that is more appropriate for regional resource disputes. While we have not yet examined the case of large countries in exactly the same setting, Skaperdas and Syropoulos (2002) analyze a setting in which the terms of trade are determined through bargaining, while Skaperdas and Syropoulos (1996) examine a case where prices are influenced by the contestants.

\section{Contesting a Resource: A Simple Model of Globalization and Insecurity}

We illustrate the main ideas discussed above within a framework that combines the key features of the model presented in Skaperdas and Syropoulos (2001) for the case of international conflicts and of the model presented in Garfinkel, Skaperdas, and Syropoulos (forthcoming) for the case of domestic conflicts. ${ }^{10}$ Consider two parties that can be, depending on the context, countries, groups or individuals. Provided that the parties are identical, our analysis applies to both international conflict and domestic conflict. For most of the presentation, we need not specify the identity of the parties. They can be different groups within a single country or each can represent a different country.

There are two factors of production. One factor is land. The other factor is labor. Neither party has secure claims to land. That is to say, all available land or "territory", denoted by $T_{o}$, is contested. Each party $i$, however, has a secure endowment of $R$ units of labor resources, which can be transformed, on a one-to-one basis, into "guns," denoted by $G_{i}$, or used to produce also

\footnotetext{
${ }^{10}$ The model we present here is a generalization of the model in Skaperdas and Syropoulos (2001), allowing us to examine additional issues. It is also a special case of the model in Garfinkel, Skaperdas, and Syropoulos (forthcoming), which allows for different degrees of insecurity and includes a number of other findings and in-depth analyses of issues like the relation to the natural-resource curse.
} 
on a one-to-one basis "food," a final good valued for consumption. Given party $i$ 's guns choice, $G_{i}, R-G_{i}(\geq 0)$ units of labor will be available for the production of food; therefore, party $i$ 's maximal production of food will be $\max \left\{R-G_{i}, 0\right\} .{ }^{11}$

Goods for final consumption, food and oil, are produced under perfectly competitive conditions. Clearly, the names we are using here are not meant to imply that the model applies to environments that involve these commodities only, but other ones that might be contestable (e.g. diamonds, precious metal, even agricultural production) or not. The goods can be traded domestically or, depending on the trade regime, internationally. Let $O_{i}$ and $N_{i}$, represent party $i$ 's consumption of oil and food (or "nutrients") respectively. The preferences of each party $i$ take the Cobb-Douglas form,

$$
U\left(O_{i}, N_{i}\right)=O_{i}^{\alpha} N_{i}^{1-\alpha}
$$

$i=1,2$ where $\alpha \in(0,1)$.

We suppose that the two parties have secure possession over the goods they produce and over those they exchange, as well as their labor endowments, $R$. Thus, the only matter of dispute between the two parties concerns the territory, $T_{o} \cdot{ }^{12}$ Both parties would like to take control of the contested territory, particularly for its oil. However, due to imperfect institutions of governance and enforcement, claims to this territory can be settled only via overt conflict or, equivalently in our model, under the threat of conflict.

It is precisely the contestability of this territory that motivates the two countries to allocate resources to guns. In particular, a party's production of guns enhances the share of $T_{o}$ it can secure. More formally, the share of $T_{o}$ that party $i$ secures, $q_{i}$, depends positively on the relative amount of

\footnotetext{
${ }^{11}$ Note that "guns" can stand for any costly appropriative activity that subtracts from useful production and welfare - e.g., ordinary rent-seeking, influence activities or litigation.

${ }^{12}$ Insofar as exchange reflects the factor content of goods traded, it should not matter for our central results whether the commodities or the factors used to produce them are subject to dispute. Furthermore, that all territory is insecure simplifies the algebra considerably, but is not critical, as shown in Skaperdas and Syropoulos (2001, 2002) and Garfinkel, Skaperdas and Syropoulos (forthcoming).
} 
guns it produces as follows:

$$
q_{i} \equiv q_{i}\left(G_{1}, G_{2}\right)=\frac{G_{i}}{G_{1}+G_{2}}
$$

if $G_{1}+G_{2}>0$; otherwise, $q_{i}=\frac{1}{2}$, for $i=1,2$. According to this specification, the share of territory that party $i$ secures in the contest is increasing in its own allocation of resources to arms, $\frac{\partial q_{i}\left(G_{1}, G_{2}\right)}{\partial G_{i}}>0$ for $i=1,2$, and decreasing in the allocation to arms by the other party, $\frac{\partial q_{i}\left(G_{1}, G_{2}\right)}{\partial G_{j}}<0$ for $j \neq i$ and $i=1,2$. $^{13}$

Once the contested land is divided between the two parties according to (2), each party engages in production. Party $i$ produces $R-G_{i}$ units of food and $T_{i}=q_{i}\left(G_{1}, G_{2}\right) T_{o}$ units of oil, $i=1,2$. Each party $i$, then, chooses its consumption of oil and food, respectively $O_{i}$ and $N_{i}$, to maximize (1) subject to the constraint that its aggregate expenditure is equal to the value of its output. Letting $p_{i}$ denote the relative price of oil measured in units of labor, food, or guns, the value of party $i$ 's output or income, $Y_{i}$, is

$$
Y_{i}\left(G_{1}, G_{2}\right)=p_{i} q_{i}\left(G_{1}, G_{2}\right) T_{o}+\left(R-G_{i}\right), \quad i=1,2 .
$$

As this expression reveals, the value of party $i$ 's output, $Y_{i}$, depends not only on $i$ 's own guns, $G_{i}$, but also on those of its opponent, $G_{j}, j \neq i$. This optimizing choice, using (1) and (3), generates the following indirect utility function:

$$
V_{i}\left(G_{1}, G_{2}\right)=\nu\left(p_{i}\right)\left[p_{i} q_{i}\left(G_{1}, G_{2}\right) T_{o}+\left(R-G_{i}\right)\right] \quad i=1,2 .
$$

where $\nu(p) \equiv(1-\alpha)^{1-\alpha}(\alpha / p)^{\alpha}$ represents the marginal utility of income.

We suppose each party $i$ chooses $G_{i}$ so as to maximize the group's wel-

\footnotetext{
${ }^{13}$ This functional form, first introduced by Tullock (1980) and used extensively in the rent-seeking literature as well as in the literatures on tournaments and conflict, falls within the general class of contest success functions axiomatized by Skaperdas (1996): $q_{i}\left(G_{1}, G_{2}\right)=\frac{f\left(G_{i}\right)}{\sum_{j=1}^{2} f\left(G_{j}\right)}$, where $f(\cdot)$ is a non-negative, increasing function. Also see Hirshleifer (1989), who investigates the properties of two important functional forms of this class, including the "ratio success function," where $f(G)=G^{m}$ with $m>0$, which simplifies to (2) when $m=1$.
} 
fare, $V_{i}$ in (4). There are two potential channels through which guns have an effect. The first is the party's income, and here the effect is twofold. Ceteris paribus, a larger $G_{i}$ raises the party's income $Y_{i}$ because it increases the party's share of the contested oil $T_{o}$. At the same time, an increase in $G_{i}$ causes the party's income to fall because less labor is then available for the production of food. The second channel through which guns can affect welfare is through their possible impact on the relative price of oil. Exactly how this price may be affected depends on the trade regime in place. This dependence implies that the tradeoff between guns and food itself is not invariant to trade openness.

In what follows, we explore the implications for security costs and welfare in the following two regimes: (i) autarky, where the two parties divide the contested land (oil) according to the relative amounts of guns, and then the parties consume only the oil and food produced domestically; and, (ii) trade, where again the contested land is divided according to the relative amounts of guns, but then oil is traded for food in international markets. In the former case, the domestic market-clearing relative price of oil is a function of that party's guns, resources and preferences. In the case of trade, for simplicity and contrast, we assume both parties are "small" in world markets and thus treat the relative world price of oil, $p$, as a parameter.

\subsection{Outcomes Under Autarky}

When barriers prevent trade across national borders, each party $i$ chooses $G_{i}$ to maximize its respective payoff, $V_{i}\left(G_{1}, G_{2}\right)$, shown in (4) where $p_{i}$ is the autarkic price determined endogenously by domestic resource constraints, subject to the conflict technology shown in (2) and the labor resource constraint $G_{i} \leq R$.

To be more precise, if the parties are countries, for given guns, the domestic market-clearing price of oil in country $i, p_{i}^{A}$ is determined endogenously as

$$
p_{i}^{A}=\frac{\alpha}{1-\alpha} \frac{R-G_{i}}{q_{i} T_{o}} \quad i=1,2
$$


Given our symmetry assumptions, it should be clear that $p_{i}^{A}$ will be identical across the two countries $i: p_{i}^{A}=p^{A}, i=1,2$.

If the parties are adversarial groups within a single country, then the possibility of integrated trade within the country between those groups implies that the autarkic price is determined endogenously by an aggregate domestic market-clearing condition which is common to the two groups. That is, given the groups' gun choices, the autarkic price for both parties, $p_{i}^{A}=p^{A}$, for $i=1,2$, depends on the country's aggregate endowments of labor and land as follows:

$$
p^{A}=\frac{\alpha}{1-\alpha} \frac{2 R-G_{1}-G_{2}}{T_{o}} .
$$

However, because the conflict technology divides the contested resource among the participants, ex ante symmetry translates into ex post symmetry, and in the autarkic equilibrium our assumption that the two groups are identical implies that no trade between domestic groups takes place. ${ }^{14}$ As (5) and (6) reveal, when parties devote more labor resources to guns production, the domestic supply of food falls relative to oil, and therefore the autarkic price of oil falls.

The conflict technology implies generally that, if party $i$ 's opponent were to make no appropriative effort $\left(G_{j}=0, j \neq i\right)$, then party $i$ could seize all of $T_{o}$ by producing an infinitesimally small quantity of guns. But, neither party would leave such an opportunity unexploited. As such, the "peaceful" outcome where $G_{i}=0$ for $i=1,2$ cannot be an equilibrium outcome. Accordingly, party $i$ 's optimizing choice of guns satisfies the following firstorder condition:

$$
\frac{\partial V_{i}}{\partial G_{i}}=\nu\left(p_{i}^{A}\right)\left[p_{i}^{A} T_{o} \frac{\partial q_{i}}{\partial G_{i}}-1\right]=0 \quad i=1,2 .
$$

\footnotetext{
${ }^{14}$ By contrast, in Garfinkel, Skaperdas and Syropoulos (forthcoming), conflict between groups is modelled as a "winner-take-all contest," such that the model predicts trade, despite the assumption of ex ante symmetry. Nevertheless, the equilibrium price under autarky is independent of the ex post and ex ante distribution of guns. Furthermore, even if each group factors in the effect that its own choice of guns has on the domestic relative price, $p^{A}$, the symmetry assumption implies that they behave as if they can have no influence on the party's autarkic price at all.
} 
The first term inside the brackets weighted by the marginal utility of income, $\nu\left(p_{i}^{A}\right)$, represents the marginal benefit of producing an additional gun. An increase in party $i$ 's production of guns increases the share of land and thus oil that the party can secure. The marginal cost of producing an additional gun is represented by the second term inside the brackets, also weighted by the marginal utility of income. This marginal cost reflects the foregone opportunity for food production.

Under the assumption that the two parties are identical, the conditions in (7) for $i=1,2$, with (2) and either (5) for the case of interstate conflict or (6) for the case of intrastate conflict, imply a unique interior symmetric solution for guns, under autarky:

$$
G_{i}^{A}=G^{A}=\frac{\alpha}{2-\alpha} R, \quad i=1,2 .
$$

As revealed by this solution, the quantity of guns both parties produce is proportional to their labor endowment, $R$, and positively related to $\alpha$, which measures the relative importance of oil to the two parties. The solution for guns implies further that each party controls one-half of the contested territory, $q_{i}=\frac{1}{2}$ for $i=1,2$, and thus can extract and consume $O^{A}=T_{i}=$ $\frac{1}{2} T_{o}$ units of oil. In addition, each party $i=1,2$ produces and consumes $N^{A}=R-G^{A}=\frac{2(1-\alpha)}{2-\alpha} R$ units of food in the autarkic outcome.

\subsection{Outcomes under Free Trade}

When the barriers to trade are removed, party $i$ chooses $G_{i}$, subject to the resource constraint $G_{i} \leq R$, to maximize its respective payoff as shown in (4), with $p_{i}=p$, which indicates the international relative price of oil (or equivalently land). ${ }^{15}$ The first-order conditions to this problem for $i=1,2$, given by

$$
\frac{\partial V_{i}}{\partial G_{i}}=\nu(p)\left[p T_{o} \frac{\partial q_{i}}{\partial G_{i}}-1\right]=0 \quad j \neq i ; i=1,2
$$

\footnotetext{
${ }^{15}$ Assuming that parties are "small" relative to the global economy, their choices take that price as given.
} 
at an interior optimum, are essentially the same as the first-order conditions to the analogous problem under the assumption of no trade, (7) for $i=$ 1,2 . But, the conditions in (9) that treat $p$ as fixed imply the following equilibrium choices for guns:

$$
G_{i}^{F}=G^{F *}=\frac{1}{4} p T_{o}, \quad i=1,2 .
$$

As the solution reveals, the optimizing choice of guns under free-trade is increasing in the value of the contested resource, $p T_{o}$, whereas the equilibrium choice of guns under autarky, $G^{A}$ as shown in (8), is not related at all to the contested resource but instead to the secure resource, $R$, and the parameter that indicates the relative importance of oil in the determination of payoffs. Thus, despite the apparent similarities between the two sets of first-order conditions, (7) and (9), the incentives to arm under the two regimes are quite different, both qualitatively and quantitatively. The production of guns is higher under trade relative to that under autarky, the larger is the endowment of contested land relative to that of labor $\left(T_{o} / R\right)$, the higher is the price of oil relative to food $(p)$, and the less important is oil $(\alpha)$.

\subsection{The Relative Appeal of Free Trade}

Is it possible for the extra cost of guns to be high enough so as to outweigh the gains from trade relative to autarky? To make such a comparison, we need to calculate equilibrium welfare under the two regimes.

Combining the solution for guns (8) under autarky with either (5) or (6) shows the following solution for the autarkic price:

$$
p_{i}^{A}=p^{A *}=\frac{4 \alpha}{2-\alpha} \frac{R}{T_{o}} \quad i=1,2 .
$$

In turn, using this expression with (8) and the payoff function (4), we can find the equilibrium payoff obtained by each player $i$ under autarky, $V_{i}^{A}$ :

$$
V_{i}^{A}=V^{A *}=\left[\frac{1}{2}\right]^{\alpha}\left[\frac{2(1-\alpha)}{2-\alpha}\right]^{1-\alpha} T_{o}^{\alpha} R^{1-\alpha} \quad i=1,2,
$$


Similarly, combining (10) with (4) gives us the parties' equilibrium payoffs under trade, $V_{i}^{F}(p)$ :

$$
V_{i}^{F}(p)=V^{F *}(p)=\nu(p)\left[\frac{1}{4} p T_{o}+R\right], \quad i=1,2,
$$

which can be shown to be strictly quasi-convex in the price of oil, $p$, reaching its minimum at a price, $p_{\min }=\frac{4 \alpha}{1-\alpha} \frac{R}{T_{o}}$. This critical price is greater than the autarkic price, $p^{A *}$, shown in (11). Furthermore, given the strict quasiconvexity of $V^{F *}(p)$, there exists another price, $p^{\prime}>p_{\min }$, which is defined uniquely by the condition, $V^{F *}\left(p^{A}\right)=V^{A *}=V^{F *}\left(p^{\prime}\right)$, such that for a range of international prices, $p \in\left(p^{A *}, p^{\prime}\right)$, both parties prefer autarky to trade.

Figure 1, which depicts the parties' payoffs under free trade $\left(V^{F *}\right)$ relative to their payoffs under autarky $\left(V^{A *}\right)$ as a function of the world price of oil $(p)$, illustrates the central results of this model of trade and conflict:

(i) For $p<p^{A *}$ and $p>p^{\prime}$, welfare under autarky is higher than welfare under trade $\left(V^{A *}>V^{F *}(p)\right)$.

(ii) For $p^{A *}<p<p^{\prime}$, welfare under trade is higher than welfare under $\operatorname{autarky}\left(V^{F *}(p)>V^{A *}\right)$.

Thus, even in the presence of contestable resources, importing countries unambiguously benefit from removing barriers to trade. Exporting countries are more likely to benefit the higher is the world price, but more generally increasing the degree of trade openness is not necessarily welfare-enhancing.

The underlying logic here is straightforward: When the international price of land or oil is sufficiently low $\left(p<p^{A *}\right)$, the two parties anticipate the opportunity to buy oil cheaply-i.e., in exchange for a relatively small fraction of their output of food-and accordingly, devote fewer labor resources to guns relative to what they would choose under autarky $\left(G^{F *}<G^{A *}\right)$. In this case, the shift away from the autarkic regime to free trade brings with it not only the familiar gains from trade, but also a reduction in the cost of conflict. When the world price equals the autarkic price, $p=p^{A *}$, the particular trade regime in place has no relevance for the 
valuation of the contestable good $\left(G^{F *}=G^{A *}\right)$, implying that the costs of conflict under trade are identical to those under autarky; at the same time, there are no gains from trade. But, when the international price of the contested resource is higher than its autarkic price, $p>p^{A *}$, the stakes of the contest between the two parties exceed those under autarky. Thus, a shift from autarky to free trade would imply that the two parties allocate more labor resources to guns under the free-trade regime relative to the autarkic regime, $G^{F *}>G^{A *}$. Of course, when $p>p^{A *}$, there are positive gains from trade too. However, provided $p^{A *}<p<p^{\prime}$, those gains are not sufficiently large to offset the added cost of conflict under free trade. That is, a shift from autarky to trade induces a welfare loss. Only when the price of land is sufficiently high (i.e., $p>p^{\prime}$ ) will the gains from trade again be greater than the additional costs of guns under trade, as depicted in Figure $1 .{ }^{16}$

It is important to emphasize that, while our presentation has been based on some very simple specifications for utility and technology, the possible negative effects of increasing globalization we have identified here are very general. This robustness can be verified simply by differentiating party $i$ 's indirect utility function with respect to $p$, while invoking the envelope theorem:

$$
{\frac{d V_{i}^{F}}{d p}}^{F}=\nu(p)\left[-M_{i}^{F}+T_{o} \frac{\partial q_{i}}{\partial G_{j}}\left(d G_{j}^{F} / d p\right)\right], \quad j \neq i ; i=1,2
$$

where $M_{i}^{F}=\alpha Y^{F} / p-q_{i} T_{o}$ is the excess demand for oil, obtained from Roy's identity and the fact that $\partial Y_{i} / \partial p=q_{i} T_{o}$. The first term inside the brackets weighted by the marginal utility of income represents the welfare effect of an exogenous increase in the relative price of oil on the gains to trade. If party $i$ is an importer of oil $\left(M_{i}^{F}>0\right)$, the effect is negative;

\footnotetext{
${ }^{16}$ Our discussion here has implicitly assumed, for convenience, that the labor resource constraint, $R-G_{i} \geq 0$, is not binding. However, as the solution for $G^{F *}$ in (10) shows, there exists some world relative price of oil, denote it by $\widetilde{p}$, such that, at $p=\widetilde{p}$, the parties fully exhaust their labor resource; any further increase in $p$ beyond $\widetilde{p}$ yields only the gains from trade. Nevertheless, since $G^{A *}<R$ as shown in (8), $\widetilde{p}>p^{A *}$. Therefore, the effective welfare minimizing world price, given by $\min \left\{\tilde{p}, p_{\min }\right\}$, is strictly greater than the autarkic price, $p^{A *}$, implying that, even when the labor resource constraint binds, there exists some range of world prices under which both parties prefer autarky to trade.
} 
otherwise $\left(M_{i}^{F}<0\right)$, the effect is positive. Hence, the gains from trade are convex in the world price, reaching a minimum at the point where the world price equals the autarkic price, $p=p^{A}$. The second term inside the brackets weighted by the marginal utility of income represents the welfare effect of the price increase on the costs of conflict. To be more precise, an increase in the international price of oil raises the stakes of the contest, thereby inducing the opponent to devote more labor resources to guns as can be seen in (10):

$d G_{j}^{F} / d p>0$. From equation (2), the increase in the opponent's guns choice implies a reduction in party $i$ 's share of land and thus oil: $\partial q_{i} / \partial G_{j}<0$ for $i \neq j=1,2$. As such, the costs of conflict under trade are monotonically increasing in the world price. At $p=p^{A}$, the costs are identical to those realized under autarky, but for $p<p^{A}\left(p>p^{A}\right)$ they are smaller (larger).

Furthermore, the particular assumption of price-taking behavior is convenient and can easily be relaxed without changing the main findings. Skaperdas and Syropoulos (2002), for example, allow for bargaining over the price of land. By the same token, the findings do not hinge on the particular way in which conflict has been modelled here. Findlay and Amin (2000), for instance, consider a trade model in which security is modelled as a public good and is increasing in one party's defense expenditures and decreasing in the defense expenditures of the another party. Findlay and Amin find that the gains from trade can be outweighed by the higher defense costs brought about by trade.

\subsection{Other Implications and Issues}

Interstate conflicts had been frequent and very costly up to World War II. World War I, in particular, took place just after the first big wave of globalization, which was also a time of intense competition for colonies and resources between the Great powers. Since World War II, however, while the frequency of interstate wars has fallen, civil wars have increased in frequency. Indeed, most of the carnage and, arguably, much economic stagnation and even retrogression since World War II can be attributed to civil wars [see Collier et. al. (2003)]. Yet, as we have already hinted, the approach we 
have presented above applies to intrastate conflicts as well as to interstate conflicts.

Our approach further provides an explanation for the "natural resource curse," the tendency of many resource-rich parties to have low or negative rates of growth despite the high prices of their exports. Trade not only makes exporters of contested resources worse off relative to the autarkic regime; it also leaves them vulnerable to declining welfare as increases in the prices for their exports would tend to increase the cost of domestic conflict. As Mehlum et. al. (2006) argue, the key appears to be the security and governance of potentially contestable resources. Countries that have solved the problem of conflict over resources do well, whereas those that have not solved the problem can face declining welfare in the face of the seeming (and fleeting) prosperity that can come from higher oil or other export prices.

In addition, Garfinkel, Skaperdas and Syropoulos (forthcoming) find that the presence of insecure land endowments distorts the pattern of trade between that country and others relative to the hypothetical scenario where land endowments are perfectly secure. In particular, when the world price of oil falls within a certain price range, the contest between domestic groups over valuable resources reverses the direction of trade. Whereas the country as a whole would be a net importer of the good that uses the contestable resources intensively in production contestable resource (oil) if groups had secure claims on $T_{o}$, in the presence of conflict, the country is a net exporter. More generally, for all world prices, the presence of domestic conflict imparts a positive bias on the country's exports.

The comparison between autarky and complete trade openness is too stark for many contexts. In practice, there are a number of other instruments that parties, groups, or even individual actors could employ to minimize the potentially harmful conflict costs of greater openness to trade and exchange. Authors in different but similar contexts have argued that wage subsidies [Zak (1995) and Grossman (1995)], land reform [Horowitz (1993) and Grossman (1994)], and market interventions in general [Dal Bo and Dal Bo (2004)] can be optimal in the face of various types of conflict, 
from common crime, to low-level political conflict, to insurrections, civil wars, and interstate wars. In a somewhat different vein, Martin, Mayer, and Thoenig (2005) have examined, both theoretically and empirically, the effects of multilateral trade relative to those of bilateral trade on the probability of conflict, and found how an increase in multilateral trade openness may increase such a probability.

Another way to think of the conflict costs that we have explored in this section in relation to trade and exchange is as a large component of the often-discussed, yet rarely modelled or operationalized, concept of "transaction costs." Taking these costs into account indicates that exchange is neither likely to emerge nor necessarily optimal in a second-best world, and can explain many practices and institutions that would be difficult to comprehend in a world with zero enforcement and conflict costs.

\section{Looking Ahead at Governance and Insecurity}

Economic globalization without security is like putting the cart before the horse, especially when the terrain is not flat. The danger for both the cart and the horse tumbling down a hill (or, worse, into a crevasse, like it was for the first part of the twentieth century) is high. Though economists have been emphasizing lately the importance of the security of property rights for economic performance, there has been scant attention paid to the costliness of either security or insecurity, how these concretely affect resource allocation and efficiency, and how security might be achieved.

Thomas Friedman's "hidden fist" and Martin Wolf's "jurisdictional integration" point, respectively, to the role of coercive capacity as the ultimate source of enforcement and the importance of uniform or harmonized governance in providing security and predictability in economic transactions. Both are necessary for the effective security of property rights. They are also costly and difficult to achieve and economists know very little about how to do it. There are however some trends and options regarding the future of governance that have been identified by some social scientists that we briefly discuss next. 


\subsection{Governance in Low-Income Countries}

Most countries in the world today do not have anything resembling modern governance, with effective laws, functioning courts, police, and bureaucracies. To have, for example, property rights in land - which as we have discussed in section 2 many countries do not effectively have - a country needs a legislative body with the ability to commit to the staying power of the laws it creates, a title agency and trained civil servants, police and courts that will enforce the laws, the professional infrastructure of lawyers, judges, surveyors, or bureaucrats (and the universities that will train them), and the belief that the process of securing title is routine and free of corruption. Otherwise, a break anywhere in this chain of property rights enforcement brings the whole edifice down. Clearly, it is expensive to have modern governance and therefore it should not be surprising that most countries, since they cannot afford it, do not have modern governance. Not only is that the case, but there are signs that governance and insecurity might be getting worse in many low-income countries. That is part of the general trend identified by Fukuyama (2004, p.119): "For well over a generation, the trend in world politics has been to weaken stateness. ... [T] he growth of the global economy has tended to erode the autonomy of sovereign nation-states by increasing the mobility of information, capital, and, to a lesser extent, labor."

Furthermore, economic liberalization itself reduces tariff revenue, a major source of government revenue for low-income countries, and therefore reduces the state's capacity to accomplish the objectives it sets. With reference to sub-Saharan Africa, Herbst (2000) has argued that external recognition of states whose borders were determined by former colonial masters - instead of by geography, similarity of culture, and internal political development - has led to the severe underdevelopment of African states. In addition, Fukuyama argues that the governments of the West, the International Financial Institutions, and NGOs actually undermine state capacity in many low-income countries. $^{17}$

\footnotetext{
17 "Policymakers in the development field should at least swear the oath of doctors to 'do no harm' and not initiate programs that undermine or suck out institutional capacity in the name of building it." [Fukuyama (2004, p.42).]
} 
"Failed" states and barely functioning states span the globe: in the Americas, from Bolivia and Peru in the South all the way North to Guatemala; all of Africa with the exception of South Africa; much of Southeastern Europe; all of the Middle East and Central Asia; much of Southeast Asia, including Indonesia; as well as Papua Guinea and Vanuatu in Oceania. ${ }^{18}$ It is by now recognized almost across the spectrum of informed opinion that weak states do not serve anybody's interests (with the possible exception of those who run such states). Thus, Fukuyama (2004, p.120) argues:

Strengthening these states through various forms of nation-building is a task that has become vital to international security but is one that few developed countries have mastered. Learning to do state-building better is thus central to the future of world order.

If, however, international institutions with the targeted interventions they undertake tend to weaken already weak states, as Fukuyama has previously argued in the same book, how could developed countries engage in successful "nation-building" without negating the very idea of a "strong state," unless of course it is a wholly-owned subsidiary of the "developed countries," the "international community," or some other outside entity? Would that ever be achievable? Is this what the future holds?

It appears, however, that internal insecurity in low-income countries is very much connected to what occurs in the rest of the world. Thus, transnational governance appears to be important for the internal governance of low-income countries, and it is not just important for resolving disputes between individual countries and avoiding future superpower confrontations. We thus conclude with a brief discussion of transnational governance.

\footnotetext{
${ }^{18}$ An illuminating map of such a division of the world can be found in the front and back flaps of Barnett (2004), where the world is divided into a "functioning core" of states and the "non-integrating gap" of either failed or barely-functioning states. Although one could argue with Barnett's particular designation of boundaries, we think the basic dichotomy is analytically useful. Barnett's own analysis, however, leaves much to be desired and could be characterized as utopian. For example, he characterizes the U.S. as having a "unique capacity to export security aound the planet" [Barnett (2004, p.7)] and appears to call for massive interventions to do so.
} 


\subsection{Transnational Governance}

The power vacuum that exists and is, arguably, expanding within many countries will be filled one way or another. Local strongmen, one possible way of filling the vacuum, are not likely to serve today's economic prerequisites or share the international and domestic legitimacy (that has economic functions as well). If, as another option of filling the power vacuum, "nationbuilding" were to take place by outsiders, how much would the interests of the insiders - the inhabitants of the countries - be taken into account? Wouldn't there be a need to have checks on the outsiders by the insiders? Would it even be possible, even if the outsiders were to know perfectly well how to "build nations" (a highly doubtful proposition at the current state of knowledge), to do so without provoking internal reactions that would negate such an attempt? Is, then, old-style imperialism an option?

The old-style, allegedly liberal, British imperialism has received a second positive look by Ferguson (2002) and others recently. But before imperialism had a serious chance at revival, it experienced a rude reversal in the dust and sands of Mesopotamia. Thus, with a Hobbesian solution to the world's governance problems appearing to be out of the question for now, Lockean or Rousseauan contractarian solutions are more promising.

One possibility is the strengthening of international organizations like the UN, by providing it with some enforcement powers, sources of independent or, at least, predictable, revenues, and mechanisms of decision-making that would allow greater representation of those who are affected by its decisions (like the citizens of countries that require building or re-building their states).

Another complementary possibility is the continued evolution and expansion of regional organizations like the European Union or Mercosur. Leonard (2005) even argues that the European Union model holds high promise as the transnational organizational structure that is well-adapted to the problems of the twenty-first century, in the sense that it strengthens governance in those countries that aspire to join, improves transnational decision-making - especially when compared to other eras when the risk of 
war was continually looming over Europe - and has multiple layers of checks and balances so as to allow for as much representation and legitimacy as would be feasible in such transnational organizations.

Both international and regional institutions and organizations are likely to be strengthened in this century. The main question is how fast will they be strengthened. For they need strengthening so as to forestall upheaval and wars that are unforeseeable in terms of their precise timing, nature, and length but which are generally predictable when the insecurity that exists today within and across many countries is allowed to evolve unchecked. Economic globalization without politically harmonized globalization is more dangerous the longer it lasts without adjustments.

\section{References}

Barbieri, K. and G. Schneider. (1999). "Globalization and Peace: Assessing New Directions in the Study of Trade and Conflict." Journal of Peace Research 36(4): 387-404.

Barnett, T.P.M. (2004). The Pentagon's New Map: War and Peace in the Twenty-First Century. New York: G.P.Putnam's Sons.

Collier, P., V.L. Elliott, H. Hegre, A. Hoeffler, M. Reynal-Querol, N. Sambanis. (2003). Breaking the Conflict Trap; Civil War and Development Policy, World Bank Policy Report. Washington, DC: World Bank and Oxford University Press.

Dal Bo, E. and P. Dal Bo. (2004). "Workers, Warriors and Criminals: Social Conflict in General Equilibrium." Working Paper, University of California-Berkeley.

Fearon, J.D. and D.D. Laitin. (2003). "Ethnicity, Insurgency, and Civil War." American Political Science Review 97(1): 75-90.

Ferguson, N. (2002), Empire: The Rise and Demise of the British World Order and the Lessons from Global Power. New York: Basic Books.

Findlay, R. and M. Amin. (2000). "National Security and International Trade: A Simple General Equilibrium Model." Working Paper, Columbia University, New York. 
Fukuyama, F. (2004). State-Building: Governance and World Order in the 21st Century. Ithaca, NY: Cornell University Press.

Garfinkel, M.R., S. Skaperdas, and C. Syropoulos. (forthcoming). "Globalization and Domestic Conflict." Journal of International Economics.

Gowa, J. (1995). Allies, Adversaries, and International Trade. Princeton: Princeton University Press.

Grossman H.I. (1994). "Production, Appropriation, and Land Reform. American Economic Review 84(3): 705-712.

Grossman H.I. (1995). "Robin Hood and the Redistribution of Property Income." European Journal of Political Economy 11(3): 399-410.

Herbst, J. (2000). States and Power in Africa: Comparative Lessons in Authority and Control. Princeton: Princeton University Press.

Hess, G.D. (2003). "The Economic Welfare Cost of Conflict: An Empirical Assessment." CESifo Working Paper, No. 852.

Hirshleifer, J. (1989). "Conflict and Rent-Seeking Success Functions: Ratio Vs. Difference Models of Relative Success." Public Choice 63(2): 101112.

Horowitz, A.W. (1993). "Time Paths of Land Reform: A Theoretical Model of Reform Dynamics." American Economic Review 83(4): 10031010 .

Jacques, M., (2005). "Victims of the Convulsions Now Transforming China." The Guardian (October 11).

Joll, J. (1992). The Origins of the First World War (2nd ed.). New York: Longman.

Kaplan, R.D. (2002). Warrior Politics: Why Leadership Demands a Pagan Ethos. New York: Random House.

Klare, M.T. (2001). Resource Wars: The New Landscape of Global Conflict. New York: Henry Holt and Company.

Leonard, M. (2005). Why Europe Will Run the 21st Century. New York: Public Affairs.

Lewis, W.W. (2004). The Power of Productivity: Wealth, Poverty, and the Threat to Global Stability. Chicago: University of Chicago Press.

Lucas, R.E. (1987). Models of Business Cycles. Oxford, UK: Basil Black- 
well.

Martin, P., T. Mayer and M. Thoenig. (2005). "Make Trade Not War?" CEPR Working Paper No. 5218.

McGuire, M. and M. Olson. (1996). "The Economics of Autocracy and Majority Rule: The Invisible Hand and the Use of Force." Journal of Economics Literature 34(1): 72-96.

Mehlum, H., K. Moene, and R. Torvik. (2006). "Institutions and the Resource Curse.” Economic Journal 116(1): 1-20.

Polachek, S.W. (1980). "Conflict and Trade." Journal of Conflict Resolution Vol. 24(1): 55-78.

Rodrik, D. (1998). "Where Did All the Growth Go? External Shocks, Social Conflict, and Growth Collapses." NBER Working Paper No. 6350 .

Rodrik, D. (1999). The New Global Economy and Developing Countries: Making Openness Work. Baltimore: Johns Hopkins University Press. Skaperdas, S. (1996). "Contest Success Functions." Economic Theory 7(2): 283-290.

Skaperdas, S. and C. Syropoulos. (1996). "Competitive Trade With Conflict, In M.R. Garfinkel and S. Skaperdas (Eds.). The Political Economy of Conflict and Appropriation. New York: Cambridge University Press.

Skaperdas, S. and C. Syropoulos. (2001). "Guns, Butter, and Openness: On the Relationship Between Security and Trade." American Economic Review, Papers and Proceedings 91(2): 353-357.

Skaperdas, S. and C. Syropoulos. (2002). "Insecure Property and the Efficiency of Exchange." Economic Journal 112: 133-146.

Tullock, G. (1980). "Efficient rent seeking." In: J.M. Buchanan, R.D. Tollison, and G. Tullock (Eds.). Toward a Theory of the Rent Seeking Society. College Station: Texas A\&M University Press.

Waltz, K.N. (1979). Theory of International Politics. Boston: McGraw Hill.

Wolf, M. (2004). Why Globalization Works. New Haven: Yale University Press. 
Zak, P.J. (1995). "Institutions, Property Rights and Growth." Working Paper, Claremont Graduate School, California. 


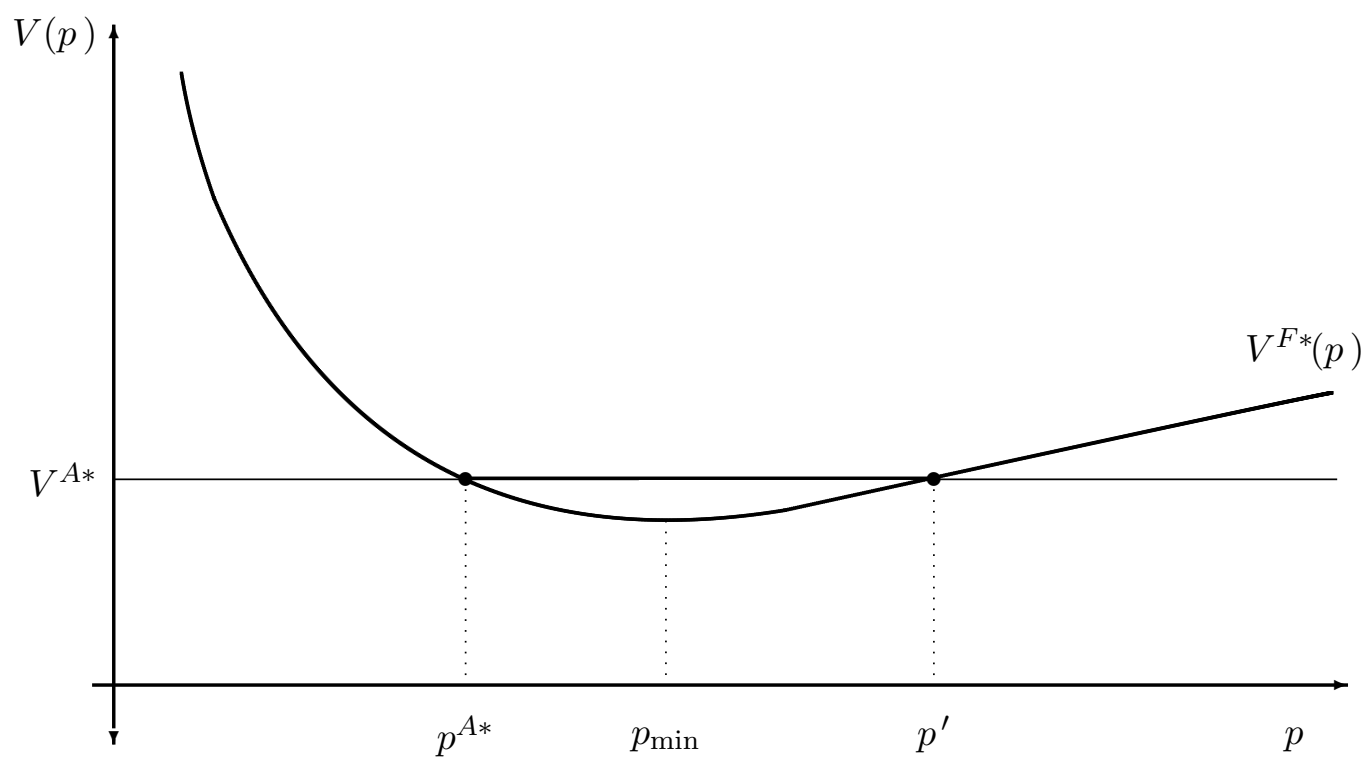

Figure 1: Free trade vs autarchy in the presence of conflict 